$\begin{array}{r}\text { WAGENINGEN } \\ \hline\end{array}$

Africa and the Demographic Consequences of the Columbian Exchange

Frankema, E.

This is a "Post-Print" accepted manuscript, which has been published in "Asian Review of World Histories"

This version is distributed under a non-commercial no derivatives Creative Commons (c) (1) $\theta \Theta$

(CC-BY-NC-ND) user license, which permits use, distribution, and reproduction in any medium, provided the original work is properly cited and not used for commercial purposes. Further, the restriction applies that if you remix, transform, or build upon the material, you may not distribute the modified material.

Please cite this publication as follows:

Frankema, E. (2019). Africa and the Demographic Consequences of the Columbian Exchange. Asian Review of World Histories, 7(1-2), 66-79.

https://doi.org/10.1163/22879811-12340046 


\title{
Africa and the Demographic Consequences of the Columbian Exchange
}

\section{Ewout FRANKEMA}

Wageningen University, Netherlands

ewout.frankema@wur.nl

\begin{abstract}
Patrick Manning has been one of the leading scholars of African historical demography since the late 1970s. This essay takes stock of his contribution to the field and highlights some of the debates in which Manning has participated over the past forty years. The essay also discusses some of the main challenges of extrapolating African population series into previous centuries, arguing that the models designed by Manning capture the potential negative consequences of the trans-Atlantic slave trade on African population development since 1500 well, but that the next step forward requires methods for estimating the positive effects of the introduction and diffusion of New World food crops in Africa.
\end{abstract}

\section{Keywords}

Africa, historical demography, Columbian exchange, Patrick Manning

\section{Manning's Contribution to African Historical Demography}

There is perhaps only one point that all students of African historical demography agree on, namely, that debates on long-term African population will never be settled with hard evidence. The chronic lack of empirical sources concerning population developments during the pre-colonial era and the questionable reliability of sources for the colonial era - colonial population censuses in particular - has provoked a lot of speculation, but hardly any conclusive investigation. From the 1930 s to the 1980 s the study of African demography has 
attracted a considerable number of historians, but it seems that frustration about "scanty evidence" (Fetter 1990) led to a brain-drain during the 1990s and 2000s, which was only partly compensated for by country- or region-oriented studies by Gwyn Campbell on Madagascar (1991), Sarah Louise Walters on the Mwanza in Tanzania (2009), and Shane Doyle on Uganda (2006, 2013). In this respect Patrick Manning's (2010) publication of new African population series for the century between 1850 and 1950 reignited a debate that had been buried for decades. His work shifted the lens back to the macro level. Manning was able to capitalize on more than three decades of research into questions regarding the long-term evolution of African populations: When did Africa's current population boom take off? How did export slavery affect African populations from 1650 to 1850 ? What was the impact of the scramble for Africa and the subsequent imposition of colonial rule? Can Africa before 1850 be characterized as an "underpopulated" continent, or do we need to revise this idea? These are all fundamental questions for the writing of African history.

Manning's early publications focused on the demographic consequences of the transAtlantic slave trade $(1979,1981)$. He developed methods to simulate the effects that export slavery may have had on the reproductive capacity of African societies, and especially the coastal slave-trading regions. These analyses were central in the composition of his widely cited monograph Slavery, Colonialism, and Economic Growth in Dahomey, 1640-1960 (1982), which dealt with one of the major slave-producing states of West Africa. As his work on African demography progressed, Manning broke the questions on African demography down into several interconnected sub-questions and started new projects to tackle these. For instance, he dived into the Indian Ocean trade and the various intra-African slave trade systems and developed a new method to project African population series back in time, using the census estimates of the 1950s-1960s as a point of departure (Manning 1990, 2010). Meanwhile, he continued to refine his simulation models of the demographic impact of slave 
exports for the period 1650-1850 and ran these with new generations of slave export data (Manning and Griffiths 1988; Manning 2014).

Manning's unrelenting effort to work with, and around, the "scanty evidence" that discouraged many of his colleagues has led to a distinctively revisionist perspective on the evolution of African populations in the past five centuries. His view challenges the dominant narrative that Africa has long been an underpopulated continent in comparison to Eurasia (Herbst 2000; Iliffe 2007; Austin 2008). This narrative holds that Africa experienced a fundamental transition in human settlement patterns only in the first half of the twentieth century, a transition currently culminating in booming population numbers. ${ }^{1}$ Manning's overarching argument is that the historical size of African populations has been systematically underestimated and that the growth of African populations between 1500 and 1950 has been systematically overstated. His readjustment of continental population series suggests that density levels were considerably lower than in Eurasia in 1850, but that this is far less evident

I gratefully acknowledge financial support from the European Research Council under the European Community's Seventh Framework Programme for the project "Is Poverty Destiny? A New Empirical Foundation for Long-Term African Welfare Analysis (ERC Grant Agreement $n^{\circ} 313114$ ); and from the Dutch Science Foundation for the project "Is Poverty Destiny? Exploring Long Term Changes in African Living Standards in Global Perspective" (NWO VIDI Grant no. 016.124.307).

${ }^{1}$ According to the United Nation's population database and trends forecasts based on a midfertility scenario, the total African population will rise from about 220 million in 1950 to 4.4 billion in 2100. This implies a twenty-fold increase in African population densities (from ca. 7.5 up to 150 persons $/ \mathrm{km} 2$ ) and a shift in Africa's share of the global population from less than 10 percent in 1950 to about 40 percent in 2100 (UN 2017). 
for 1650. Instead, Manning's estimates point to a "dense early modern African population" $(2014,131)^{2}$

Figure 1 shows Manning's estimates of total African population along with previous estimates made by Colin McEvedy and Richard Jones (1978), Angus Maddison (2010), Walter Francis Willcox (1931), and Alexander Carr-Saunders (1936). Manning's baseline continental population estimate of 140 million during the high tide of the oceangoing slave trades (ca. 1650-1870) marks the upper end of the spectrum. But Manning's estimates also stand apart because they are the only ones underpinned by simulation models of population development informed by the latest generation of slave export data from the Trans-Atlantic Slave Trade Database. His approach demonstrates how the evidence that is available can be put to use in order to create a new basis for future research.

Figure 1. African population estimates, 1500-1950.

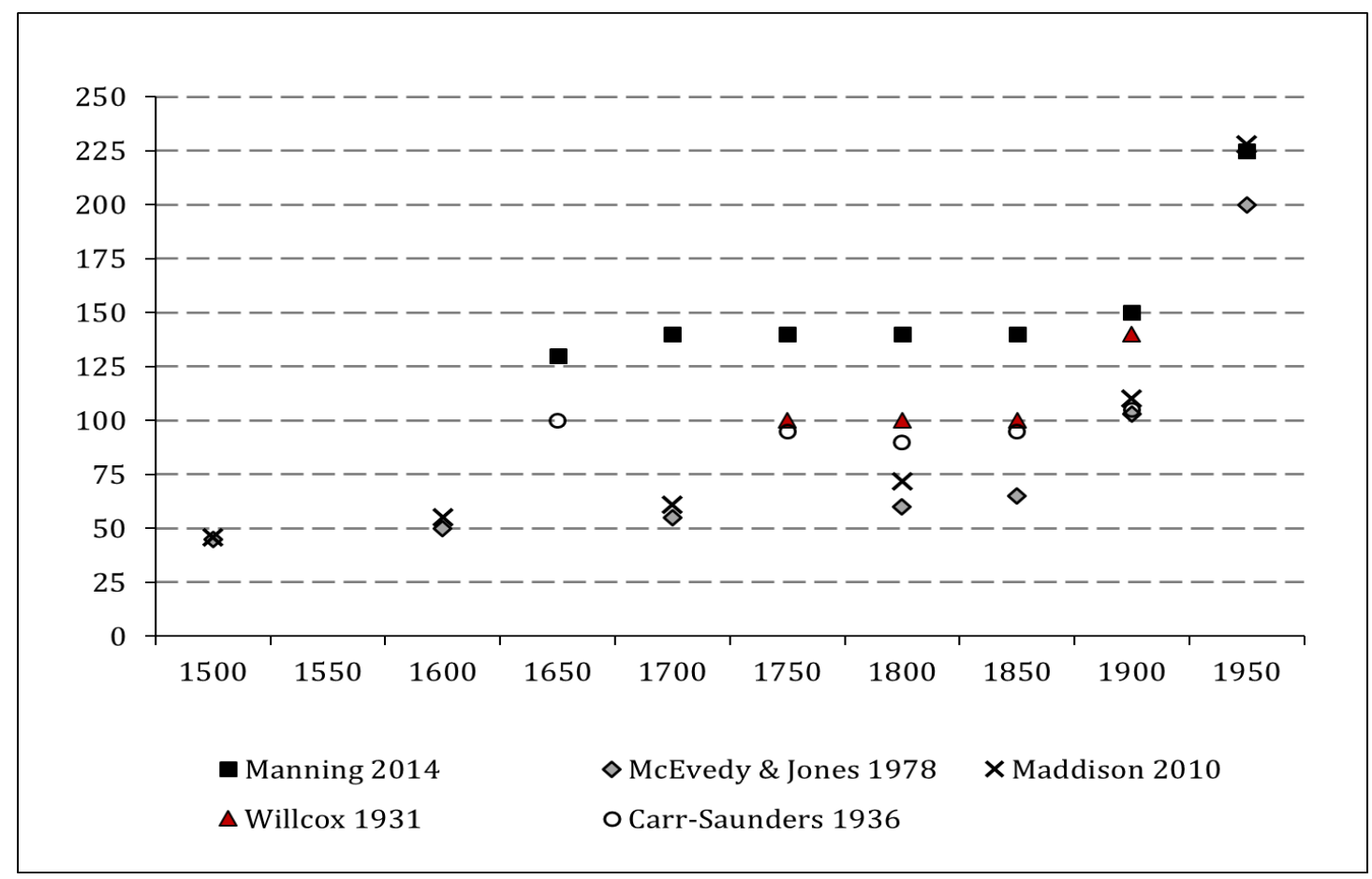

Source: Data drawn from Manning 2014, 137, fig. 4.1.

${ }^{2}$ Part of Manning's recent work has been in cooperation with Scott Nickleach. 
Manning's contribution to African historical demography is thus hard to

underestimate. The remainder of this essay will focus on a topic that Pat and I have discussed in person various times in recent years, but which goes back to an old question that played a central role in the debates he had with colleagues in the late 1970s and 1980s: How did the arrival of New World food crops affect the reproductive capacity of African populations? Did the expansion of the cultivation choice-set of African farmers and related widening of the subsistence basis offset the demographic losses of export slavery? And is Manning's estimate of 140 million for the era $1650-1850$ realistic in light of this widening subsistence basis? I beg to differ.

\section{Export Slavery and New World Food Crops}

In 1979 Manning criticized the argument made by John Fage a decade earlier that the Atlantic slave trade had had a much smaller impact on African population dynamics than scholars had hitherto assumed (Fage 1969, Manning 1979, Caldwell et al. 1982). Fage had argued that the numbers of exported slaves were much lower than previously estimated and that the share of females in the trade was too limited to erode the reproductive capacity of West African societies. Fage received partial support from John Thornton (1980), who used the Portuguese censuses of 1777 and 1778 to argue that exported captives could be replaced by natural rates of population growth. Manning defended the opposite view and introduced a first version of a model to compute the demographic impact of slave exports. The argument about the low female share in Atlantic slave exports continued to be made (Caldwell and Schindlmayr 2002), but Manning used new generations of slave export data to refine his estimations. 
The question of how to account for the introduction of American food crops kept returning. In his 2014 chapter Manning commented: "The adoption of American crops by African farmers is known to have taken place from 1500, but we do not yet have precise information on the pace of adoption or on the nutritional or demographic results of that agricultural change, and cannot simply assume that it overcame all other factors to generate steady population growth" (148). My response to that statement is: neither can we be sure that it didn't.

It is indisputable that export slavery, and the violence associated with it, has constrained the growth of West African populations between 1650 and 1850 and those of East African populations especially during the first three quarters of the nineteenth century. At the same time it seems hard to believe that the diffusion and adoption of New World food crops across sub-Saharan Africa left the reproductive capacity of African societies untouched, even though one can only guess about the when, where, and to what extent. The problem with Manning's simulation models is that this factor is entirely left out. The logical consequence of this omission is that Manning's population estimates understate natural rates of demographic growth, although we do not know when, where, and to what extent.

There are four things we think we do know about the potential impact of the diffusion of American crops. First, all the main food crops, including maize, cassava, sweet potatoes, coco-yams, groundnuts, squash, tomatoes, and a variety of beans and pulses have made their way into the cultivation systems of millions of African farmers, alongside several Asian crops such as bananas/plantains, sugar cane, and Asian rice. During the second half of the twentieth century, maize and cassava even became two of the largest four staples in terms of annual caloric intake in Africa south of the Sahara, being cultivated across a wide variety of savannah and forest eco-zones (FAO 1949; rice and sorghum/millets are the other two). 
Maize is used for human consumption and for feeding livestock. Linguistic evidence suggests that maize was adopted in the coastal areas of tropical Africa at various locations and at different times. Traveler accounts reveal that in the sixteenth century the crop was "widely grown along the coast from the River Gambia to Sâo Tomé, around the mouth of the River Congo, and possibly in Ethiopia" (Miracle 1965, 39). According to Wilks (1993) maize was key to opening up the West African forest zone to sedentary farming. There are seventeenthcentury references for Zanzibar and the Ruvuma river in present-day Tanzania. Slave ship records reveal that maize was important in the provisioning of slave ships between the Gulf of Guinea and Biafra during the seventeenth and eighteenth centuries (Dalrymple-Smith and Frankema 2017). Maize seems to have been adopted later in the interior of Central and East Africa - probably at different points in the nineteenth century—where it only gained significance as the primary food staple in the twentieth century (McCann 2005). In Southern Africa maize gained importance with the spread of white settler farmers who endorsed the crop in millet-oriented regions (Jenkin 2018, ch. 5).

The diffusion of cassava probably started after the introduction of the plant from Brazil in the major slave-trading areas of the Southwest (i.e., present-day Angola and the Congo) during the sixteenth century. Eighteenth-century sources reveal that manioc was grown in Madagascar and Mozambique (Crosby 2003 [1972], 187). Although the crop can mature in nearly any kind of soil under highly variable climatologic conditions, its diffusion across Africa was probably slower than the diffusion of maize. One of the reasons may have been that the process of leeching out its poison may have taken time to be perfected. Another reason may be slow adaptation to the specific taste of the crop and limited possibilities for integration into local cuisine. According to W. O. Jones (1969), the spread of cassava probably gained momentum only during the second half of the nineteenth century. 
Second, there appears to be a consensus that the introduction of the potato and maize in Europe was essential to sustain the accelerated expansion of European populations in the eighteenth and nineteenth centuries (Salaman 1989; Crosby 2003 [1972]; Heiser 1990; McNeill 1991). These crops extended the cultivation choice-set of European farmers — and of Asian farmers for that matter-and widened opportunities for agricultural intensification. Maize could be grown on relatively poor soils and hillside slopes that were unsuitable for prevalent cereal crops. Part of the maize crops were used for human consumption and formed the basis for local dishes (e.g., polenta in Northern Italy), but most of the crop was used to feed livestock (McNeill 1999). The potato was especially valuable in densely populated areas where land was scarce. Although the calorie content of a kilogram of potatoes is much less than that of a kilogram of cereal flour, yields per hectare are much larger. For the poor peasants in Northern Europe the potato became a life-saver. Nathan Nunn and Nancy Qian (2011) have estimated that the potato alone may have accounted for about a quarter of the growth in Old World populations between 1700 and 1900, the bulk of which, according to Nunn and Qian, took place in Eurasia. If maize and potatoes were important for broadening the subsistence basis in Europe, what would maize, cassava, and a range of other crops from the American tropics have meant for human subsistence and reproduction in the African forest zones?

Third, the advantages of American food crops for the cultivation choice-set of African farmers were more obvious than for Europe and Asia, where the four major cereals (wheat, barley, millet, rice) were widespread (Crosby 1972, 185; McCann 2005; Caldwell and Schindlmayr 2002). Maize and cassava are drought-resistant crops that can thrive in semi-dry savannah zones as well as forest regions and many mosaic landscapes in between. Cassava is particularly valuable as a famine-preserve crop, as it can be kept in the ground up to thirty-six months and harvested at the desired time of consumption (Lebot 2009). Maize has the 
advantage, compared to millet and yams, that it requires a shorter time to mature and can provide two harvests per year if soils and rainfall regimes (two rounds of rain per annum) permit. Maize also had the particular advantage of being a so-called C4 crop with a specific process of photosynthesis that requires high degrees of light-energy, but modest amounts of carbon dioxide in order to grow most efficiently. This makes maize particularly suitable for rapid growth in tropical environments, with high temperatures and varying rainfall conditions. In addition, beans and pulses, groundnuts, sweet potatoes, and coco-yams also all thrive in tropical climates.

Table 1 suggests that especially in the forest zones of sub-Saharan Africa, these crops made an important addition to the limited choice of staple foods available. Unlike parts of Europe, where land has become an increasingly scarce production factor during the past millennium, the crucial importance of the American crops in sub-Saharan Africa was that they created new possibilities to spread the risks of climatic variability across varying food crops and that they added important new sources of calories, protein, and other nutrients. These features were particularly valuable in the settlement of Africa's forest zones, where yams were the dominant staple. Yams may have been domesticated, selected, and cultivated in the African forest zones for about seven thousand years and have the desirable property that they can be stored for half a year without losing much nutritional value. The downside, however, is that the tubers are not great sources of calories and protein and are also a poor source of essential amino acids (Lebot 2009). New World staples thus significantly enlarged the subsistence basis of African food producers in two ways: more nutrients, and more opportunities to mitigate cultivation risk.

Table 1: Nutritional value of European, African and American staples. 


\begin{tabular}{|c|c|c|}
\hline European staples & $\mathrm{kcal} / \mathrm{kg}$ & protein grams $/ \mathrm{kg}$ \\
\hline Wheat flour & 3,500 & 140 \\
\hline Barley flour & 3,560 & 120 \\
\hline Rye flour & 3,410 & 100 \\
\hline Oatmeal & 3,850 & 170 \\
\hline \multicolumn{3}{|c|}{ African staples (savannah) } \\
\hline Rice, milled & 3,600 & 27 \\
\hline Millet & 3,400 & 110 \\
\hline \multicolumn{3}{|c|}{ African staples (forest) } \\
\hline Yams & 900 & 15 \\
\hline \multicolumn{3}{|l|}{ New World staples } \\
\hline Maize flour & 3,600 & 90 \\
\hline Cassava & 1,600 & 14 \\
\hline Coco-yams & 900 & 15 \\
\hline Sweet potatoes & 900 & 16 \\
\hline Potatoes & 700 & 20 \\
\hline \multicolumn{3}{|c|}{ New World complements } \\
\hline Groundnuts, shelled & 5,700 & 250 \\
\hline Beans and pulses & 350 & 210 \\
\hline
\end{tabular}

Source: Data derived from the first food composition tables constructed by the FAO (1949, 1953), "Food composition tables for international use," downloadable at http://www.fao.org/docrep/x5557e/x5557e00.htm. Note: Nutritional values of food crops differ across places and change over time. The values reported in this table are indicative and only serve to underpin the point that the introduction of New World 
staples in African agriculture significantly enlarged the potential supply of calories and protein.

Table 1 shows indeed that the advantages of New World food crops were not primarily related to higher calorie or protein values. Moreover, compared to millets it is hard to think of foodstuffs, either cereals or tubers, with such a rich palette of vitamins and minerals. Cassava is poorly endowed with vitamins and minerals and should therefore really be taken for what it was: a very cheap source of calories that can be stored for long periods in order to overcome seasonality in the availability of calories. Maize had more to offer in terms of vitamins and minerals, especially in those places where it complemented yams as the main staple. Although yams contain far more vitamin $\mathrm{C}$, maize provides much of the essential amino acids, iron, zinc, sodium, and vitamins B2, B3, and B6 (USDA 2018).

Fourth, we know that both cassava and maize played a key role in the provisioning of slave ships. Portuguese traders brought large quantities of manioc flour from Brazil to the Southwest African coast in present-day Angola and the Congo in order to feed the slaves on the return voyage (Miller 1979, Newson 2007). Poor diets based almost exclusively on cassava may have accounted for exceptionally high mortality rates. Maize was important in the provisioning of slave forts and ships in the Gold Coast. In the Bight of Biafra the supply consisted mainly of yams. As Angus Dalrymple-Smith and I (2017) have argued, it remains unclear whether local African food markets sufficed to provision the trade, but it seems certain that without maize and manioc the nutritional foundation of the trans-Atlantic slave trade would have been much weaker in many places.

Although the role of American food crops in the provisioning of the slave trade has received considerable attention — as well as the role of African crops (e.g., rice) in the food 
supplies of New World slave plantations (Carney and Rosomoff 2011) — the strategic importance of maize and cassava was wider than that. To create scale economies in slaveraiding activities, local armies had to be supplied with weapons as well as food reserves. If the guns and gunpowder supplied by European traders were essential in the production of slaves, food rations were crucial for the distance and duration of slave-raiding campaigns. The warring states that rose to power in the West African forest zones of Upper Guinea, such as Asante, Dahomey and Oyo, were in a position to use the double harvests of maize to smoothen annual food supplies, create surpluses and to intercrop maize cultivated on newly cleared plots with cassava and coco-yams. It is conceivable that this combination of American food crops played a crucial role in the timing of the rise of these states. As Wilks has argued for Asante (1993), these states gained ascendancy on the basis of a successful extension of local food supplies (see also McCann 2005).

In Southwest Africa, where the major slave-trading ports of Benguela and Luanda emerged as exponents of a bilateral slave trade with Brazil, cassava was the prime strategic crop (Miller 1997). Manioc flour was produced on Brazilian plantations in order to supply slave ships with large amounts of calories required to keep hundreds of slaves alive during a journey of several months. We lack any detailed information on how many of the calories were supplied by manioc cultivated in Brazil and in the coastal regions of present-day Angola or the Congo, but the scale of the trade obviously demanded that significant amounts of manioc flour be produced in both regions. As was the case with maize production in parts of West Africa, experimentation with the cultivation of cassava must have been widespread and this, in turn, must have stimulated a process of diffusion of the crop further inland. Slaves who were captured inland had to be kept alive during their journeys to the coast and during the weeks or months in captivity before embarkation. Control over these food reserves was thus of great military-strategic and economic importance. 


\section{When Did African Populations Start to Grow?}

Manning is right that it is not evident that the introduction of these foodstuffs overcame the human losses incurred by centuries of export slavery, but thus far the introduction of maize, cassava, and a range of other foodstuffs have not been factored into his simulation models. Much of the positive demographic impact will have depended on the speed of diffusion and the location-specific added value of these crops in comparison with the existing cultivation complexes. Let us suppose, for the moment, that this process of diffusion was slow and that the demographic impact was not significant enough to influence the evolution of African populations between 1650 and 1850 . What would this imply for Manning's backward projections for the century 1850 to 1950 ? For, around the turn of the twentieth century, references to maize and cassava are so widespread that the demographic impact of American food crops can no longer have been negligible.

For his 1850-1950 projections Manning (2010) used a fine-grained model of growth variables which he cast upon a "default population growth rate" derived from Indian censuses starting in the 1870 s, and adjusting these imposed growth rates for specific regional and temporal developments which he termed "situational modifications," including disease epidemics and famine, colonial disorder, slave-trade related disorder, cross-regional migration patterns, post-slave trade recovery, and income growth.

Manning's approach was challenged in a paper I wrote together with Morten Jerven (2014). In this paper we argued that the use of Indian censuses for the construction of a "default growth rate" may lead to biases because Indian population growth rates were depressed significantly by recurrent famines in the late nineteenth century (Roy 2012), while Southeast Asian populations grew (much) faster. If a default growth rate already includes the effects of local (i.e., Indian) situational modifications and one subsequently deducts local 
African modifications, these "bad" effects are counted twice. Moreover, the evidence that the demographic developments in North and Southern Africa differed substantially from those in tropical Africa is strong enough to call into question the applicability of a single default growth series. We also argued that it may be unwise to dismiss all of the potential information that may be extracted from African colonial censuses, given the variation in the coverage and quality of these historical records. We revised Manning's estimates taking these arguments into account and arrived, in the latest version of the Frankema-Jerven dataset, at a total African estimate in 1850 of 106 million, which brings us closer to the older estimates by Willcox and Carr-Saunders. ${ }^{3}$

Yet, neither Manning nor Frankema and Jerven have given much consideration to the possibility of major changes in the agricultural subsistence basis of (colonial) African populations, and this is most likely to be our most important common omission. A crucial part of a future research agenda into the demographic dynamics of the century before 1950 is to explore what colonial accounts have to say about local cultivation practices and mix of food crops. For if maize, cassava, sweet potatoes, coco-yams, and groundnuts were absent from the continent in 1500, but dominant in many places around 1950, a more complete set of "situational modifications" would include the introduction and diffusion of important new sources of calories, protein, vegetable oils, and vitamins. This addition will also force us to reconsider the idea of dense early-modern African populations.

\footnotetext{
${ }^{3}$ For the dataset see www.aehnetwork.org/dfata\&research.
} 


\section{Conclusion}

Manning's leadership in African historical demographic research is of great importance. He has been one of the very few scholars to engage with this topic during a lifetime career.

Without his work, the debate would not have been restarted. Without his work, scholars may still have accepted the estimates of Maddison as the best available, while they clearly are not. Most important, however, is that Manning has shown the field new ways to use the information that is available in order to make conjectures with some empirical ground. I hope that more scholars find it worthwhile to invest their energy and capacities in the improvement of these conjectures and that new research into the diffusion of New World food crops will be integrated in Manning's original simulation models. 


\section{References}

Austin, Gareth. 2008. "Resources, Techniques, and Strategies South of the Sahara: Revising the Factor Endowments Perspective on African Economic Development History.” Economic History Review 61(3): 587-624.

Caldwell, John C., Joseph E. Inikori, and Patrick Manning. 1982. "Two Comments on Manning. 'The Enslavement of Africans: A Demographic Model,' CJAS/RCEA 15 (1981), and a Response." Canadian Journal of African Studies 16 (1): 127-139.

Caldwell, John C., and Thomas Schindlmayr. 2002. "Historical Population Estimates: Unraveling the Consensus.” Population and Development Review 28 (2): 183-204. Campbell, Gwyn. 1991. "The State and Pre-Colonial Demographic History: The Case of Nineteenth-Century Madagascar." Journal of African History 32 (3): 415-445.

Carney, Judith Ann, and Richard Nicholas Rosomoff. 2011. In the Shadow of Slavery: Africa's Botanical Legacy in the Atlantic World. Berkeley: University of California Press.

Carr-Saunders, Alexander M. 1936. World Population: Past Growth and Present Trends. New York": Oxford University Press.

Crosby, Alfred W. 2003 (1972). The Columbian Exchange: Biological and Cultural Consequences of 1492. Westport, CT: Praeger.

Dalrymple-Smith, Angus, and Ewout Frankema. 2017. "Slave Ship Provisioning in the Long 18th Century: A Boost to West African Commercial Agriculture?” European Review of Economic History 21 (2): 185-235.

Doyle, Shane. 2006. Crisis \& Decline in Bunyoro: Population \& Environment in Western Uganda, 1860-1955. London; Oxford; Kampala; Athens, Ohio: British Institute in Eastern Africa; in association with James Currey; Fountain Publishers; Ohio University Press. 
Doyle, Shane. 2013. Before HIV: Sexuality, Fertility, and Mortality in East Africa, 19001980. Oxford: Oxford University Press.

Fage, John D. 1969. "Slavery and the Slave Trade in the Context of West African History." The Journal of African History 10 (3): 393-404.

FAO. 1949, 1953 (2nd ed.). Food Composition Tables for International Use. Rome: FAO. http://www.fao.org/docrep/x5557e/x5557e00.htm (accessed November 11, 2017).

Fetter, Bruce. 1990. Demography from Scanty Evidence: Central Africa in the Colonial Era. Boulder: L. Rienner.

Frankema, Ewout, and Morten Jerven. 2014. "Writing History Backwards or Sideways: Towards a Consensus on African Population, 1850-2010.” Economic History Review 67 (4): 907-931.

Heiser, Charles B. 1990. Seed to Civilization: The Story of Food. Cambridge, MA: Harvard University Press.

Herbst, J. 2000. States and Power in Africa: Comparative Lessons in Authority and Control. Princeton: Princeton University Press.

Iliffe, John. 2007. Africans: The History of a Continent. 2nd ed. New York: Cambridge University Press.

Jenkin, S. 2018. Foreign Investment in Agricultural Development. The Past of the Present in Zambia. Lund, Sweden: Media-Tryck, Lund University.

Jones, W. O. 1969. Manioc in Africa. Stanford: Stanford University Press.

Lebot, Vincent. 2009. Tropical Root and Tuber Crops: Cassava, Sweet Potato, Yams, Aroids. Wallingford, UK: CABI.

Maddison, Angus. 2010. "Historical Statistics on World Population, GDP and Per Capita GDP, 1-2008 AD.” http://www.ggdc.net/maddison/ (accessed October 27, 2017). 
Manning, Patrick. 1979. “The Slave Trade in the Bight of Benin, 1640-1960.” In The Uncommon Market: Essays in the Economic History of the Atlantic Slave Trade, edited by Henry A. Gemery and Jan S. Hogendorn, 109-141. New York: Academic Press.

Manning, Patrick. 1981. “The Enslavement of Africans: A Demographic Model.” Canadian Journal of African Studies 15 (3): 499-526.

Manning, Patrick. 1982. Slavery, Colonialism, and Economic Growth in Dahomey, 16401960. Cambridge: Cambridge University Press.

Manning, Patrick. 1990. Slavery and African Life: Occidental, Oriental, and African Slave Trades. Cambridge: Cambridge University Press.

Manning, Patrick. 2010. “African Population: Projections, 1851-1961.” In The Demographics of Empire: The Colonial Order and the Creation of Knowledge, edited by Karl Ittmann, Dennis D. Cordell, and Gregory H. Maddox, 245-275. Athens: Ohio University Press.

Manning, Patrick. 2014. “African Population, 1650-2000: Comparisons and Implications of New Estimates." In Africa's Development in Historical Perspective, edited by Emmanuel Kwaku Akyeampong, Robert H. Bates, Nathan Nunn, and James A. Robinson, 131-152. Cambridge, MA: Cambridge University Press.

Manning, Patrick, and William S. Griffiths. 1988. "Divining the Unprovable: Simulating the Demography of African Slavery.” The Journal of Interdisciplinary History 19 (2): $177-201$.

McCann, James C. 2005. Maize and Grace: Africa's Encounter with a New World Crop, 1500-2000. Cambridge, MA: Harvard University Press.

McEvedy, Colin, and Richard Jones. 1978. Atlas of World Population History. New York: Penguin Books. 
McNeill, William H. 1991. “American Food Crops in the Old World.” In Seeds of Change: A Quincentennial Commemorative, edited by Herman J. Viola and Carolyn Margolis, 43-59. Washington, DC: Smithsonian Institution Press.

Miller, Joseph Calder. 1997. Way of Death: Merchant Capitalism and the Angolan Slave Trade, 1730-1830. Wisconsin: University of Wisconsin Press.

Miracle, Marvin P. 1965. "The Introduction and Spread of Maize in Africa.” The Journal of African History 6 (1): 39-55.

Newson, Linda A. 2007. From Capture to Sale: The Portuguese Slave Trade to Spanish South America in the Early Seventeenth Century. Leiden: Brill.

Nunn, Nathan, and Nancy Qian. 2011. “The Potato’s Contribution to Population and Urbanization: Evidence from a Historical Experiment." Quarterly Journal of Economics 126 (2): 593-650.

Roy, Tirthankar. 2012. Natural Disasters and Indian History. New Delhi: Oxford University Press.

Salaman, Redcliffe N. 1989. The History and Social Influence of the Potato. Cambridge: Cambridge University Press.

Thornton, John K. 1980. “The Slave Trade in Eighteenth Century Angola: Effects on Demographic Structures.” Canadian Journal of African Studies 14 (3): 417-427.

UN. 2017. World Population Prospects 2017. https://esa.un.org/unpd/wpp/ (accessed November 1, 2017).

USDA. 2018. United States Department of Agriculture Food Composition Databases. https://ndb.nal.usda.gov/ndb/nutrients/index.

Walters, Sarah Louise. 2009. "Fertility, Mortality and Marriage in Northwest Tanzania, 19201970: A Demographic Study Using Parish Registers.” Ph.D. diss., University of Cambridge. 
Willcox, Walter Francis. 1931. "Increase in the Population of the Earth and Its Continents since 1650.” In International Migrations, vol. 2, Interpretations, 31-81. New York: National Bureau of Economic Research.

Wilks, Ivor. 1993. Forests of Gold: Essays on the Akan and the Kingdom of Asante. Athens: Ohio University Press. 